JP3I (Jurnal Pengukuran Psikologi dan Pendidikan Indonesia), 7(I), 2018, 22-32

D0l: http://dx.doi.org/10.15408/p3i.v7il.12105

http://journal.uinjkt.ac.id/index.php/jp3i

\title{
UJI VALIDITAS KONSTRUK PSYCHOLOGICAL WELL-BEING SCALE DENGAN METODE CONFIRMATORY FACTOR ANALYSIS (CFA)
}

\author{
Fikri Mubarok Miftahuddin \\ UIN Syarif Hidayatullah Jakarta \\ mubarokfikri@gmail.com
}

\begin{abstract}
The purpose of this study is to examine construct validity from psychological well-being scale. In this study researchers tested six dimensions of psychological well-being from Ryff (1989), namely, self-acceptance, positive relations with others, autonomy, environmental mastery, purpose in life, and personal growth with a total of 42 items. The research subjects were nurses at one of the hospitals in Jakarta Cempaka Putih consisting of I7I people. The data analysis method used in this study is confirmatory factor analysis (CFA) with the help of listel 8.70 software. Based on calculations using the CFA method it can be concluded that all dimensions require modification of the measurement model to obtain a fit value.
\end{abstract}

Keywords : construct validity; psychological well-being scale; psychological well-being; confirmatory factor analysis

\begin{abstract}
Abstrak
Tujuan dari penelitian ini adalah untuk menguji validitas konstruk dari psychological well-being scale. Dalam penelitian ini peneliti menguji enam dimensi psychological well-being dari Ryff (I989) yaitu, self-acceptance, positive relation with others, autonomy, environmental mastery, purpose in life, dan personal growth dengan jumlah 42 item. Subjek penelitian adalah perawat pada salah satu Rumah Sakit di Jakarta Cempaka Putih yang terdiri dari I7I orang. Metode analisis data yang digunakan dalam penelitian ini adalah confirmatory factor analysis (CFA) dengan bantuan software lisrel 8.70. Berdasarkan perhitungan dengan metode CFA dapat disimpulkan bahwa semua dimensi memerlukan modifikasi model pengukuran untuk memperoleh nilai fit.

Kata kunci: validitas konstruk, psychological well-being scale, psychological well-being, confirmatory factor analysis
\end{abstract}




\section{Pendahuluan}

Munculnya psychological well-being sebagai istilah dalam kajian ilmu psikologi merupakan usaha dari peneliti-peneliti untuk melihat bagaimana manusia memiliki kebahagiaan. Awalnya, ilmuwan psikologi menaruh perhatian besar apa yang membuat seseorang menjadi tidak bahagia, dan gangguan-gangguan psikis apa yang dapat terjadi pada manusia, sehingga mengganggu kebahagiaan tersebut. Kajian mengenai psychological well-being menjadi perbincangan para ahli ketika mulai mengartikan struktur dasar dari psychological well-being, diskusi peneliti selalu berpusat pada pembedaan antara emosi negatif dan positif, serta kepuasan dalam hidup (Ryff, I989). Karya Bradburns yang muncul pada tahun 1969 yang berjudul "The Structure of Psychological well-being" dapat membedakan emosi negatif dan positif tersebut. Bradburns fokus pada kebahagiaan sebagai variabel hasil dan menyatakan bahwa emosi negatif dan positif adalah dua hal yang berbeda, dan keseimbangan pada keduanya merupakan ciri dari kebahagiaan (Ryff, I989).

Setelah bertahun-tahun, peneliti kemudian mencoba untuk melihat pada faktor-faktor yang dapat mendukung dan mendorong timbulnya positive functioning pada manusia (Diener, I984; Jahoda, 1958 dalam Ryff, I989). Perkembangan pemikiran ini terus berlanjut, dan terdapat dua paradigma besar mengenai konsep dari well-being itu sendiri. Waterman (I993, dalam Hidalgo et.al., 2010) membedakan konsep well-being dalam dua paradigma, yang pertama disebut sebagai hedonic. Paradigma hedonic fokus pada kebahagiaan dan mendefinisikan well-being sebagai indikator kualitas hidup, berdasarkan pada hubungan antara karakteristik lingkungan dan tingkat kepuasan seseorang (Campbell et.al., 1976 dalam Hidalgo et.al., 2010). Kesenangan hedonic merujuk pada emosi positif yang ada secara bersamaan dengan objek materi dan peluang tindakan untuk memiliki atau mengalaminya (Kraut dalam Waterman, 2008). Hedonic fokus pada pencapaian kepuasan dan menghindari rasa sakit (Ryan \& Deci, 200 I dalam Hidalgo et.al., 20I0). Paradigma yang kedua adalah eudemonic. Aristoteles memandang eudemonic sebagai sesuatu yang paling tinggi dari yang baik, sebagai realisasi potensi sebenarnya pada seseorang dibandingkan sebuah kebahagiaan (Ryff, I989). Eudemonic berorientasi pada hidup yang memiliki makna dan tingkat seseorang dalam pemuasan kebutuhan diri. Hal ini mendefinisikan well-being sebagai tingkat tertentu dimana seseorang menjadi pribadi yang sepenuhnya berfungsi. (Ryan \& Deci dalam Hidalgo et.al., 2010).

Selanjutnya, hedonic dianggap sebagai istilah yang mewakili subjective well-being, dan eudemonic dianggap sebagai istilah yang mewakili psychological well-being. Studi mengenai subjective well-being sendiri fokus pada afeksi dan kepuasan dalam hidup, sedangkan psychological well-being fokus pada pengembangan keterampilan dan pengembangan diri, keduanya diyakini sebagai indikator penting pada positive functioning (Diaz et.al., 2006 dalam Hidalgo et.al., 2010).

Dalam mengukur psychological well-being, sampai saat ini ada cukup banyak alat ukur yang digunakan oleh peneliti, seperti Satisfaction with Life Scale, Psychological General Well-Being Index Short, Bradburn Affect Balance Scale, dan lain-lain. Namun alat ukur yang paling sering digunakan adalah Psychological WellBeing Scale (Hidalgo et,al, 2010) yang diciptakan oleh Ryff sendiri (I989).

Penelitian ini menguji Psychological Well-Being Scale yang dikembangkan oleh Ryff (1989), karena alat ukur ini paling sering digunakan dalam mengukur psychological well-being. Di Indonesia sendiri penelitian tentang psychological well-being sudah cukup banyak dilakukan hanya saja pengujian tentang validitas alat ukur tersebut secara khusus relatif kurang mendapat perhatian. Oleh karena itu, peneliti mengadaptasi dan menguji alat ukur tersebut.

Skala psychological well-being terbagi ke dalam enam dimensi, yaitu self-acceptance, positive relation with others, autonomy, environmental mastery, purpose in life, dan personal growth (Ryff, I989). Skala pengukuran milik Ryff ini sendiri dibuat dengan format skala likert dengan 6 kemungkinan jawaban yang disediakan, mulai dari sangat tidak setuju hingga sangat setuju. 
Skala milik Ryff memiliki reliabilitas test-retest yang tinggi dan memiliki konsistensi internal yang tinggi. Koefisien test-retest tiap subskala self-acceptance adalah sebesar 0.85 , relation with others sebesar 0.83 , autonomy sebesar 0.88, environmental mastery sebesar 0.8I, purpose in life sebesar 0.82 dan personal growth sebesar 0.8I (Hidalgo et.al., 20I0). Sedangkan koefisien alpha subskala self acceptance adalah sebesar 0.93, positive relation with others sebesar 0.9I, autonomy sebesar 0,86, environmental mastery sebesar 0.90, purpose in life sebesar 0.90, dan personal growth sebesar 0.90 (Hidalgo et.al., 2010).

\section{Psychological well-being}

Dalam membangun teorinya, Ryff (1989, dalam Rathi, 20II) berlandaskan pada teori maturity milik Gordon Allport, self actualization milik Abraham Maslow, fully functioning milik Carl Rogers, individuation milik Jung, psychological stage model milik Erikson, kriteria sehat mental milik Jahoda, basic life tendencies milik Buhler, dan perubahan kepribadian pada masa dewasa dan lansia milik Neugarten. Ryff (1989) mendefinisikan psychological well-being sebagai kondisi dimana individu memliki sikap yang positif terhadap diri sendiri dan orang lain, dapat membuat keputusan sendiri dan mengatur tingkah lakunya sendiri, dapat menciptakan dan mengatur lingkungan yang cocok dengan kebutuhannya, memiliki tujuan hidup dan membuat hidup mereka lebih bermakna, serta berusaha mengeksplorasi dan mengembangkan dirinya (Ryff, 1989).

Ryff mengajukan enam aspek yang merupakan aspek dari psychological well-being. Enam aspek ini tidak lepas dari penggabungan Ryff dari berbagai teori yang menjadi rumusan dasar dari psychological well-being (dalam Ryff, 1989).

\section{a. Self-acceptance}

Self-acceptance dikatakan sebagai fitur utama dari sehat mental sebagai karakteristik dari aktualisasi diri, fungsi diri yang optimal, dan kedewasaan. Memiliki sikap yang positif terhadap diri sendiri merupakan karakteristik dari positive psychological functioning (Ryff, I989). Self-acceptance tidak merujuk pada cinta yang narsistik atau rendahnya self-esteem, tetapi merupakan penghargaan diri yang terbentuk oleh aspek negatif dan positif (Ryff \& Singer, 2003 dalam Hidalgo et.al., 2010). Orang yang memiliki nilai yang tinggi pada aspek ini mengindikasikan bahwa ia memiliki sikap yang positif, yang dapat mengenali dan menerima berbagai aspek dalam dirinya, termasuk hal-hal yang baik maupun yang buruk, dan dapat melihat pada masa lalu dengan perasaan yang positif (Ryff \& Keyes, I995). Sedangkan orang yang memiliki nilai yang rendah pada aspek ini adalah orang yang sangat tidak puas dengan dirinya sendiri, mereka tidak nyaman dengan apa yang terjadi pada masa lalunya, dan merasa khawatir tentang kualitas pribadi mereka dan memiliki keinginan untuk berubah ( Ryff \& Keyes, I995).

\section{b. Positive relationship with others}

Salah satu komponen utama dari sehat mental adalah kemampuan untuk memberikan cinta. Orang yang beraktualisasi diri digambarkan memiliki rasa empati dan afeksi yang kuat terhadap manusia dan dapat memiliki cinta yang mendalam, persahabatan yang kuat, dan memiliki identifikasi yang sempurna terhadap yang lain. Membinan hubungan yang hangat dengan orang lain merupakan salah satu dari criterion of maturity yang dikemukakan oleh Allport (Ryff, I989). Teori perkembangan pada tahap dewasa juga menekankan pentingnya hubungan yang dekat dengan orang lain. Pentingnya memiliki hubungan yang positif dengan orang lain berulang kali ditekankan dalam definisi dari psychological well-being (Ryff, I989). Skor yang tinggi pada aspek ini menunjukkan sifat yang hangat, kepuasan dan kepercayaan pada hubungan dengan orang lain, memperhatikan well-being dari orang lain dan memiliki kemampuan untuk memiliki empati, afeksi dan keakraban serta pemahaman dalam menjalin hubungan dengan orang lain (Ryff \& Keyes, 1995). Nilai yang rendah menunjukkan bahwa seseorang memiliki sedikit hubungan yang dekat dan terpercaya dengan orang 
lain, sulit untuk memiliki kehangatan, terbuka dan khawatir denga orang lain. Merekan merasa terisolasi dan frustasi dengan hubungan sosial (Ryff \& Keyes, I995).

\section{c. Autonomy}

Ryff menilai orang yang sudah mencapai tahap aktualisasi diri adalah individu yang menunjukkan fungsi kemandirian dan tahan terhadap akulturasi. Seseorang dengan fully functioning digambarkan sebagai seorang individu yang memiliki internal locus of evaluation, dimana orang tersebut tidak selalu membutuhkan pendapat dan persetujuan dari orang lain, namun mengevaluasi dirinya sendiri dengan standar personal (Ryff, 1989). Teori perkembangan menambahkan bahwa orang dengan ciri ini memiliki pendirian yang bebas dari norma-norma yang membelenggu individu pada kehidupan sehari-hari. Nilai yang tinggi pada aspek ini menunjukkan indivdidu yang berkemauan kuat dan independen, dapat menahan tekanan sosial dan bertindak dengan pandangan penilaian personal. Individu ini dicirikan dengan mengevaluasi diri dengan menggunakan standar personal (Ryff \& Keyes, I995). Sedangkan orang yang memiliki nilai rendah pada aspek ini memiliki kekhawatiran terhadap ekspektasi orang lain, bergantung pada penilaian orang lain sebelum membuat keputusan penting, dan pemikiran serta tindakan mereka dipengaruhi oleh tekanan sosial (Ryff \& Keyes, 1995).

\section{d. Environmental mastery}

Salah satu karakteristik dari kondisi seseorang yang memiliki sehat mental adalah ia memiliki kemampuan untuk memilih dan menciptakan lingkungan yang sesuai dengan kondisi psikisnya.. Dalam teori perkembangan, manusia dewasa yang sukses adalah seseorang yang memiliki kemampuan untuk memanipulasi dan mengontrol lingkungan yang kompleks, serta dapat mengambil manfaat dari lingkungan tersebut. Pandangan-pandangan ini mengindikasikan bahwa partisipasi yang aktif dan penguasaan terhadap lingkungan adalah komponen yang penting dalam integrasi kerangka teori positive psychological functioning. Individu yang baik dalam aspek ini adalah mereka yang memiliki keyakinan dan kompetensi dalam mengatur lingkungan. Individu tersebut secara efektif dapat menggunakan peluang yang muncul dan dapat memilih atau menciptakan konteks yang sesuai dengan kebutuhan dan nilai personal mereka. Mereka yang tidak memiliki indikasi yang baik pada aspek ini mengalami kesulitan dalam menangani kesulitan sehari-hari, merubah atau meningkatkan kualitas sekitarnya, kurang peka terhadap kesempatan yang ada dilingkungannya, dan kurang memiliki kontrol terhadap lingkungan (Ryff \& Keyes, I995).

\section{e. Purpose in life}

Seseorang yang memiliki sifat mental yang sehat dikatakan memiliki perasaan untuk menyadari bahwa terdapat tujuan dan makna dalam hidup. Definisi dari kedewasaan sendiri juga menekankan tujuan hidup yang menyeluruh, memiliki arah (sense of directedness) dan juga tujuan (intentionality) (Ryff, I989). Teori perkembangan dalam hal ini menekankan bahwa berbagai perubahan tujuan hidup sesuai dengan tugas perkembangan dalam tahap perkembangan tertentu. Rogers juga menambahkan bahwa orang dengan fully functioning memiliki tujuan dan cita-cita, serta rasa keterarahan yang membuat dirinya merasa hidup bermakna (Ryff, I989). Orang yang memiliki skor yang tinggi pada aspek ini memiliki tujuan dalam hidupnya dan memiliki rasa keterarahan. Mereka merasa memiliki makna baik pada kehidupan masa lalu dan masa sekarang pada kehidupan mereka, mereka memegang teguh kepercayaan yang memberikan mereka tujuan dalam hidup dan memiliki target serta alasan untuk hidup (Ryff, I989). Sedangkan orang yang memiliki nilai yang rendah pada aspek ini adalah individu yang merasa bahwa hidup mereka tidak memiliki arti apa-apa dan tidak memiliki tujuan atau rasa keterarahan. Mereka tidak dapat memahami maksud dari kehidupan masa lalu mereka (Ryff \& Keyes, I995). 


\section{f. Personal growth}

Aspek ini melihat pentingnya kemampuan seseorang untuk menyadari potensi dan bakat untuk mengembangkan potensi yang lain. Kebutuhan terhadap aktualisasi diri dan menyadari potensi diri merupakan hal yang utama dalam perspektif klinis terhadap pengembangan diri. Terbuka terhadap pengalaman merupakan salah satu ciri dari fully functioning person. Teori perkembangan menambahkan pentingnya individu untuk terus berkembang guna menghadapi tantangan baru dalam setiap periode pada tahap perkembangannya (Ryff, 1989). Orang yang memiliki skor yang tinggi pada aspek ini menunjukkan bahwa ia ingin terus berkembang. Mereka mementingkan diri sendiri untuk terus tumbuh dan berkembang, terbuka terhadap pengalaman baru, merasa bahwa ia memenuhi potensi mereka, mereka dapat melihat perkembangan pada dirinya dan perilakunya setiap waktu, dan dapat berubah menjadi pribadi yang lebih efektif dan memiliki wawasan yang bertambah (Ryff \& Keyes, I995). Sedangkan orang yang memiliki skor rendah pada aspek ini akan merasa dirinya mengalami stagnasi, tanpa perkembangan atau perubahan seiring berjalannya waktu, mereka merasa bosan dan kurang berminat dalam hidup. mereka merasa tidak mampu dalam mengembangkan sikap atau perilaku baru (Ryff \& Keyes, 1995).

\section{Metode}

Subjek penelitian sebanyak I7I perawat yang bekerja pada salah satu rumah sakit swasta di Jakarta. Alat ukur yang akan diuji adalah Psychological Well-Being Scale (PWBS) yang dikembangkan oleh Ryff (1989) yang mengukur, enam dimensi, yaitu self-acceptance, positive relation with others, autonomy, environmental mastery, purpose in life, dan personal growth. Skala PWBS berjumlah 42 item .

Untuk menguji validitas alat ukur yang digunakan dalam penelitian ini, peneliti menggunakan confirmatory factor analysis (CFA) dengan software Lisrel 8.7. Adapun langkah-langkah yang dilakukan adalah sebagai berikut (Umar, 20I I):

I. Dilakukan uji CFA pada model satu faktor kemudian dilihat nilai chi-square yang dihasilkan. Jika nilai chi-square $\left(x^{2}\right)$ yang dihasilkan adalah $<0,05$ (signifikan), maka dapat dinyatakan model tidak fit dan tidak mengukur satu faktor. Sedangkan jika nilai chi-square yang dihasilkan adalah $>0,05$ (tidak signifikan) maka dapat dinyatakan bahwa model fit dan mengkur satu faktor saja.

2. Untuk hasil model yang tidak fit pada hasil awal uji CFA, maka dapat dilakukan modifikasi model agar model menajdi fit. Modifikasi model dilakukan dengan cara membebaskan item-item yang saling berkorelasi pada model. Item-item ini diasumsikan memiliki kesalahan pengukuran sehingga perlu dilakukan modifikasi pada item-item tersebut. Dengan ditemukannya kesalahan pengukuran maka item dianggap mengukur hal lain selain apa yang hendak diukur oleh model yang diujikan.

3. Jika telah didapatkan model yang fit, maka langkah selanjutnya adalah melihat pada muatan faktor item pada model. Item tersebut harus memiliki nilai t-value yang signifikan $(>1,96)$, yang berarti bahwa item tersebut benar-benar mengukur apa yang hendak diukur sesuai dengan model pengukuran. Item yang tidak signifikan ( $T$-value $<\mathrm{I}$,96) akan di-drop.

4. Selanjutnya adalah dengan melihat nilai muatan koefisien yang ada. Jika nilai koefisien pada item adalah positif, maka item tidak akan didrop, dan sebaliknya jika nilai koefisien pada item adalah negatif maka item akan didrop.

5. Dan yang terakhir adalah jika terdapat item yang memiliki korelasi lebih dari empat kali, maka item tersebut juga akan didrop karena diasumsikan item tersebut tidak bersifat unidimensional sesuai dengan model pengukuran yang ada. 


\section{Hasil}

\section{Self acceptance}

Pada dimensi self-acceptance, hasil awal analisis CFA yang dilakukan menunjukkan bahwa model satu faktor tidak fit dengan chi-square $=65,59 \mathrm{df}=\mathrm{I} 4 \quad p$-value $=0,00000 \mathrm{RMSEA}=0,147$. Oleh karena itu peneliti melakukan modifikasi terhadap model, dimana kesalahan pengukuran pada beberapa item dibebaskan berkorelasi satu sama lainnya sampai didapatkan model fit. Setelah didapatkan model fit dengan nilai chisquare $=9,97 \mathrm{df}=9$ p-value $=0,353154$ RMSEA $=0,025$. Dari hasil tersebut menunjukkan bahwa nilai chi-square menghasilkan p-value $>0,05$ (tidak signifikan), yang artinya model dengan satu faktor (unidimensional) dapat diterima, bahwa seluruh item mengukur satu faktor saja, yaitu self-acceptance.

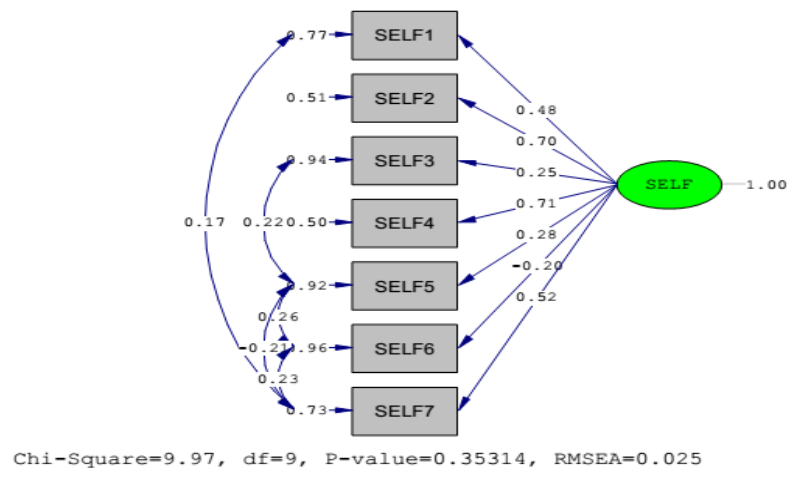

Gambar I. Hasil CFA dimensi self acceptance

\section{Positive relation with others}

Pada dimensi positive relation with others, hasil awal analisis CFA yang dilakukan menunjukkan bahwa model satu faktor tidak fit dengan chi-square $=49,86 \mathrm{df}=\mathrm{I} 4$-value $=0,0000 \mathrm{I}$ RMSEA $=0, \mathrm{I} 23$. Oleh karena itu peneliti melakukan modifikasi terhadap model, dimana kesalahan pengukuran pada beberapa item dibebaskan berkorelasi satu sama lainnya sampai didapatkan model fit. Setelah didapatkan model fit dengan nilai chi-square $=16,09 \mathrm{df}=\mathrm{I0} p$-value $=0,09700$ RMSEA $=0,060$. Dari hasil tersebut menunjukkan bahwa nilai chi-square menghasilkan $p$-value $>0,05$ (tidak signifikan), yang artinya model dengan satu faktor (unidimensional) dapat diterima, bahwa seluruh item mengukur satu faktor saja, yaitu positive relation with others.

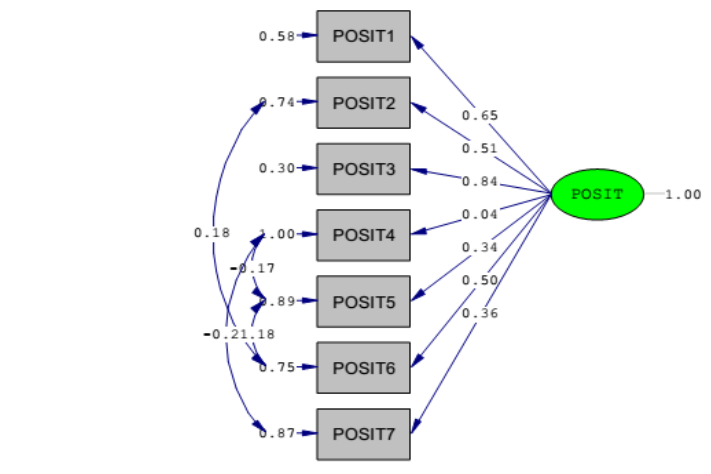

Chi-Square=16.09, df=10, P-value=0.09700, RMSEA $=0.060$

Gambar 2. Hasil CFA dimensi positive relation with others 


\section{Autonomy}

Pada dimensi autonomy, hasil awal analisis CFA yang dilakukan menunjukkan bahwa model satu faktor tidak fit dengan chi-square $=74,9 \mathrm{I} \mathrm{df}=\mathrm{I} 4$ p-value $=0,00000 \mathrm{RMSEA}=0, \mathrm{I} 60$. Oleh karena itu peneliti melakukan modifikasi terhadap model, dimana kesalahan pengukuran pada beberapa item dibebaskan berkorelasi satu sama lainnya sampai didapatkan model fit. Setelah didapatkan model fit dengan nilai chisquare $=$ I9,2I $\mathrm{df}=\mathrm{II}$-value $=0,05745 \mathrm{RMSEA}=0,066$. Dari hasil tersebut menunjukkan bahwa nilai chi-square menghasilkan p-value $>0,05$ (tidak signifikan), yang artinya model dengan satu faktor (unidimensional) dapat diterima, bahwa seluruh item mengukur satu faktor saja, yaitu autonomy.

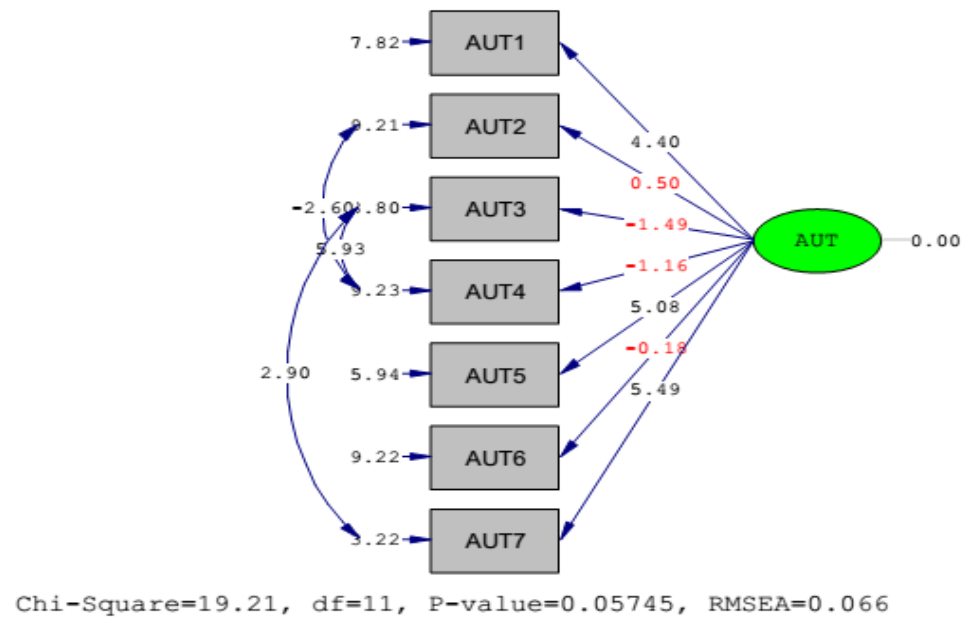

Gambar 3. Hasil CFA dimensi autonomy

\section{Environmental mastery}

Pada dimensi environmental mastery, hasil awal analisis CFA yang dilakukan menunjukkan bahwa model satu faktor tidak fit dengan chi-square $=109,48 \mathrm{df}=\mathrm{I} 4$ p-value $=0,00000 \mathrm{RMSEA}=0,200$. Oleh karena itu peneliti melakukan modifikasi terhadap model, dimana kesalahan pengukuran pada beberapa item dibebaskan berkorelasi satu sama lainnya sampai didapatkan model fit. Setelah didapatkan model fit dengan nilai chi-square $=15,7 \mathrm{I} \mathrm{df}=9$ p-value $=0,073 \mathrm{I} 7 \mathrm{RMSEA}=0,066$. Dari hasil tersebut menunjukkan bahwa nilai chi-square menghasilkan p-value $>0,05$ (tidak signifikan), yang artinya model dengan satu faktor (unidimensional) dapat diterima, bahwa seluruh item mengukur satu faktor saja, yaitu environmental mastery.

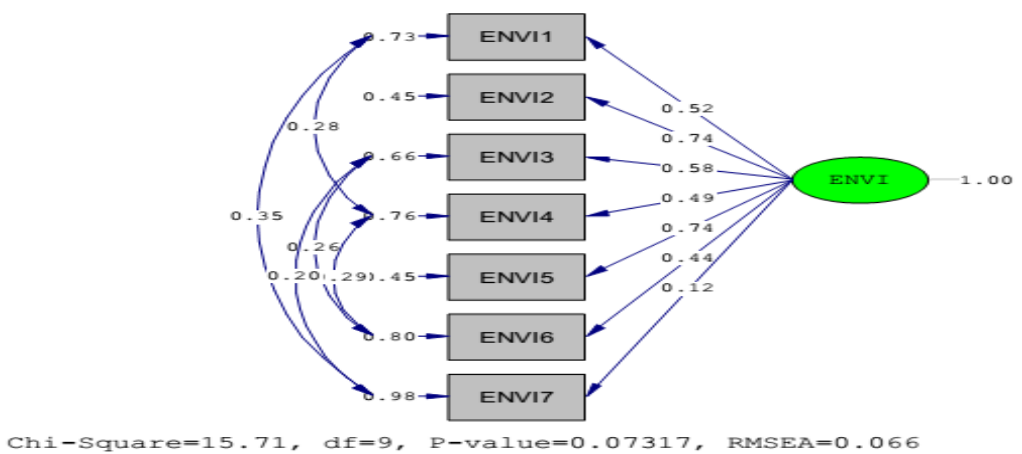

Gambar 4. Hasil CFA dimensi environmental mastery 


\section{Purpose in life}

Pada dimensi purpose in life, hasil awal analisis CFA yang dilakukan menunjukkan bahwa model satu faktor tidak fit dengan chi-square $=6 \mathrm{I}, 3 \mathrm{I} \mathrm{df}=\mathrm{I} 4 p$-value $=0,00000 \mathrm{RMSEA}=0, \mathrm{I} 4 \mathrm{I}$. Oleh karena itu peneliti melakukan modifikasi terhadap model, dimana kesalahan pengukuran pada beberapa item dibebaskan berkorelasi satu sama lainnya sampai didapatkan model fit. Setelah didapatkan model fit dengan nilai chisquare $=\mathrm{I} 6,36 \mathrm{df}=\mathrm{II} p$-value $=0,12845 \mathrm{RMSEA}=0,054$. Dari hasil tersebut menunjukkan bahwa nilai chi-square menghasilkan p-value $>0,05$ (tidak signifikan), yang artinya model dengan satu faktor (unidimensional) dapat diterima, bahwa seluruh item mengukur satu faktor saja, yaitu purpose in life.

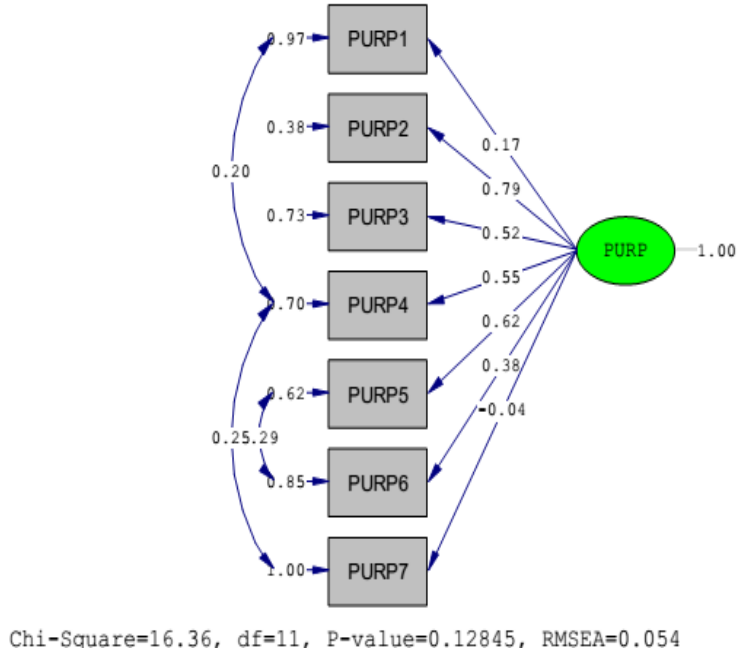

Gambar 5. Hasil CFA dimensi purpose in life

\section{Personal growth}

Pada dimensi personal growth, hasil awal analisis CFA yang dilakukan menunjukkan bahwa model satu faktor tidak fit dengan chi-square $=\mathrm{I} 55,05 \mathrm{df}=\mathrm{I} 4$ p-value $=0,00000 \mathrm{RMSEA}=0,243$. Oleh karena itu peneliti melakukan modifikasi terhadap model, dimana kesalahan pengukuran pada beberapa item dibebaskan berkorelasi satu sama lainnya sampai didapatkan model fit. Setelah didapatkan model fit dengan nilai chisquare $=9,72 \mathrm{df}=7, p$-value $=0,20506$ RMSEA $=0,048$. Dari hasil tersebut menunjukkan bahwa nilai chi-square menghasilkan p-value $>0,05$ (tidak signifikan), yang artinya model dengan satu faktor (unidimensional) dapat diterima, bahwa seluruh item mengukur satu faktor saja, yaitu personal growth.

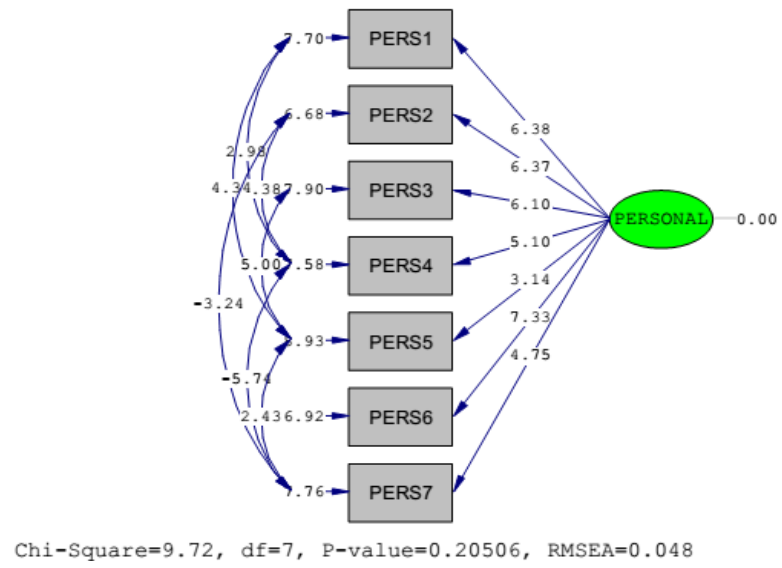

Gambar 6. Hasil CFA dimensi Personal growth 
Setelah mendapatkan model yang fit pada tiap dimensi, peneliti melihat apakah item - item yang ada mengukur faktor yang hendak diukur. Peneliti akan melihat apakah item-item yang ada memiliki koefisien bermuatan negatif karena tidak sesuai dengan sifat item yang positif (favourable), apakah signifikan item tersebut mengukur faktor yang hendak diukur $(t$-value $<$ I,96), dan apakah terdapat kesalahan pengukuran pengukuran item yang saling berkorelasi lebih dari tiga kali, karena, yang berkorelasi lebih dari tiga kali selain mengukur apa yang hendak diukur, ia juga mengukur hal lain. Jika terdapat item yang memiliki salah satu dari ketiga kriteria tersebut, item tersebut akan di-drop.

Table I. Koefisien muatan faktor masing-masing dimensi

\begin{tabular}{|c|c|c|c|c|c|c|c|c|}
\hline \multirow{2}{*}{$\begin{array}{l}\text { Variabel Instrumen } \\
\text { Psychological } \\
\text { Well-Being }\end{array}$} & \multirow[t]{2}{*}{ Penelitian } & \multirow[t]{2}{*}{ Item } & \multicolumn{3}{|c|}{ Goodness of Fit } & \multicolumn{3}{|l|}{ Seleksi Item } \\
\hline & & & $\mathrm{X}^{2}$ & $\mathrm{df}$ & $P$-value & Factor Loading & $T$-value & $\begin{array}{l}\text { Jumlah Korelasi antar } \\
\text { Item }\end{array}$ \\
\hline \multirow{7}{*}{\multicolumn{2}{|c|}{ Self-Acceptance }} & I & \multirow[t]{7}{*}{9,97} & \multirow[t]{7}{*}{9} & \multirow[t]{7}{*}{$0,353 \mathrm{I} 54$} & 0,48 & 5,54 & I \\
\hline & & 2 & & & & 0,70 & 8,68 & 0 \\
\hline & & 3 & & & & 0,25 & 2,86 & I \\
\hline & & 4 & & & & $0,7 \mathrm{I}$ & 8,80 & 0 \\
\hline & & 5 & & & & 0,28 & 3,09 & 3 \\
\hline & & $6^{\mathrm{b}}$ & & & & $-0,20$ & $-2,16$ & 2 \\
\hline & & 7 & & & & 0,52 & 5,98 & 3 \\
\hline \multirow{7}{*}{\multicolumn{2}{|c|}{$\begin{array}{l}\text { Positive Relation } \\
\text { with Others }\end{array}$}} & I & \multirow[t]{7}{*}{$\mathrm{I} 4,45$} & \multirow[t]{7}{*}{ II } & \multirow[t]{7}{*}{0,20903} & 0,65 & 8,25 & I \\
\hline & & 2 & & & & $0,5 \mathrm{I}$ & 6,24 & I \\
\hline & & 3 & & & & 0,84 & 10,79 & 0 \\
\hline & & $4^{a}$ & & & & 0,04 & $0,5 \mathrm{I}$ & 2 \\
\hline & & 5 & & & & 0,34 & $4,0 \mathrm{I}$ & I \\
\hline & & 6 & & & & 0,50 & 6,04 & 2 \\
\hline & & 7 & & & & 0,36 & 4,35 & I \\
\hline \multirow{7}{*}{\multicolumn{2}{|c|}{ Autonomy }} & I & \multirow[t]{7}{*}{19,21} & \multirow[t]{7}{*}{ II } & \multirow[t]{7}{*}{0,05745} & 0,43 & 4,40 & 0 \\
\hline & & $2^{\mathrm{a}}$ & & & & 0,05 & 0,50 & I \\
\hline & & $3^{\mathrm{ab}}$ & & & & $-0,17$ & $-1,49$ & $\mathrm{I}$ \\
\hline & & $4^{\mathrm{ab}}$ & & & & -0, II & $-\mathrm{I}, \mathrm{I} 6$ & I \\
\hline & & 5 & & & & 0,55 & 5,08 & 0 \\
\hline & & $6^{\mathrm{ab}}$ & & & & $-0,02$ & $-0,18$ & 0 \\
\hline & & 7 & & & & 0,70 & 5,49 & I \\
\hline \multirow{7}{*}{\multicolumn{2}{|c|}{$\begin{array}{l}\text { Environmental } \\
\text { Mastery }\end{array}$}} & I & \multirow[t]{7}{*}{$\mathrm{I} 5,7 \mathrm{I}$} & \multirow[t]{7}{*}{9} & \multirow[t]{7}{*}{0,07317} & 0,52 & 6,36 & 2 \\
\hline & & 2 & & & & 0,74 & 9,77 & 0 \\
\hline & & 3 & & & & 0,58 & 7,25 & 2 \\
\hline & & 4 & & & & 0,49 & $5,9 \mathrm{I}$ & 2 \\
\hline & & 5 & & & & 0,74 & 9,76 & 0 \\
\hline & & 6 & & & & 0,44 & 5,26 & 2 \\
\hline & & $7^{a}$ & & & & 0,12 & $\mathrm{I}, 43$ & 2 \\
\hline \multirow{7}{*}{\multicolumn{2}{|c|}{$\begin{array}{l}\text { Purpose } \\
\text { in Life }\end{array}$}} & I & \multirow[t]{7}{*}{16,36} & II & 0,12845 & 0,17 & 3,50 & I \\
\hline & & 2 & & & & 0,79 & 9,55 & 0 \\
\hline & & 3 & & & & 0,52 & 6,29 & 0 \\
\hline & & 4 & & & & 0,55 & 6,58 & 2 \\
\hline & & 5 & & & & 0,62 & 7,52 & I \\
\hline & & 6 & & & & 0,38 & 4,40 & I \\
\hline & & $7^{\mathrm{ab}}$ & & & & $-0,04$ & $-0,47$ & I \\
\hline Personal & & I & 9,72 & & 0,20506 & 0,55 & 6,38 & 2 \\
\hline Growth & & 2 & & & & 0,58 & 6,37 & 2 \\
\hline & & 3 & & & & 0,52 & 6,10 & I \\
\hline & & 4 & & & & 0,50 & 5,10 & 3 \\
\hline & & 5 & & & & 0,30 & 3,14 & 3 \\
\hline & & 6 & & & & 0,62 & 7,33 & 4 \\
\hline & & 7 & & & & 0,46 & 4,75 & 3 \\
\hline
\end{tabular}

\section{Keterangan:}

a item tidak memberikan informasi yang signifikan tentang konstruk $(T$-value $<$ I,96)

${ }^{b}$ item memiliki muatan faktor yang negatif

c item memiliki kesalahan pengukuran yang berkorelasi dengan item lain lebih dari tiga kali 
Melalui tabel di atas dapat dilihat bahwa pada dimensi self acceptance, item enam ternyata memiliki koefisien muatan negatif, sehingga item enam akan didrop, sedangkan item yang lain memiliki koefisien muatan yang positif, memiliki $t$-value yang lebih dari I,96 dan tidak memiliki kesalahan pengukuran korelasi dengan item lain lebih dari tiga kali, dengan demikian ada enam item yang dinilai mengukur self acceptance.

Pada dimensi positive relation with others item empat ternyata tidak memberikan informasi yang signifikan tentang konstruk, sedangkan item yang lain memiliki koefisien muatan yang positif, memiliki $t$-value yang lebih dari I,96 dan tidak memiliki kesalahan pengukuran korelasi dengan item lain lebih dari tiga kali, dengan demikian ada enam item yang dinilai mengukur positive relation with others.

Pada dimensi autonomy item tiga, empat, dan lima ternyata tidak memberikan informasi yang signifikan tentang konstruk. Selain itu item tiga, empat dan lima ternyata memiliki koefisien yang bermuatan negatif pula, sehingga item tiga, empat dan lima akan didrop. Item selain tiga, empat, dan lima memiliki koefisien muatan yang positif, memiliki $t$-value yang lebih dari I,96 dan tidak memiliki kesalahan pengukuran korelasi dengan item lain lebih dari tiga kali, dengan demikian ada empat item yang dinilai mengukur autonomy.

Pada dimensi environmental mastery item tujuh ternyata tidak memberikan informasi yang signifikan tentang konstruk, sehingga item akan didrop. Seluruh item selain item tujuh memiliki koefisien muatan yang positif, memiliki $t$-value yang lebih dari I,96 dan tidak memiliki kesalahan pengukuran korelasi dengan item lain lebih dari tiga kali, dengan demikian ada enam item yang yang dinilai mengukur environmental mastery.

Pada dimensi purpose in life item tujuh ternyata memiliki muatan koefisien negatif, sehingga item akan didrop. Seluruh item selain item tujuh memiliki koefisien muatan yang positif, memilikit-value yang lebih dari I,96 dan tidak memiliki kesalahan pengukuran korelasi dengan item lain lebih dari tiga kali, dengan demikian ada enam item yang dinilai mengukur purpose in life.

Pada dimensi personal growth seluruh item ternyata memiliki koefisien muatan yang positif, memiliki $t$ value yang lebih dari I,96 dan tidak memiliki kesalahan pengukuran korelasi dengan item lain lebih dari tiga kali, dengan demikian ada tujuh item yang dinilai mengukur personal growth.

\section{Diskusi}

Hasil penelitian menunjukkan bahwa semua dimensi dari psychological well-being yaitu selfacceptance, positive relation with others, autonomy, environmental mastery, purpose in life, dan personal growth memerlukan modifikasi untuk mencapai model fit. Setelah melakukan analisis faktor terhadap enam dimensi dari psychological well-beingmenunjukkan bahwa psychological well-being scaledapat digunakan untuk mengukur psychological well-being, namun perlu dilakukan perbaikan dan pembaharuan terhadap item-item yang bersifat multidimensional.

Dari hasil pengujian CFA menunjukkan bahwa terdapat banyak korelasi antar measurement errorpada setiap item psychological well-being. Hal ini menunjukkan bahwa item tersebut mengukur hal yang hendak diukur, ternyata juga mengukur hal yang lain(multidimensional).

Berdasarkan kesimpulan dan diskusi maka dapat disarankan bahwa:

I. Bagi peneliti selanjutnya disarankan untuk mengembangkan item dalam hal penggunaan bahasa yang sesuai dengan responden agar mudah dimengerti sehingga alat ukur yang digunakan benar-benar mengukur apa yang hendak diukur dan menghasilkan hasil yang akurat.

2. Penelitian selanjutnya diharapkan dapat melakukan identifikasi item terlebih dahulu pada tiap dimensi psychological well-being. 


\section{Daftar Pustaka}

Barret, P. (2007). Structural equation modelling: Adjudging model fit. Personality and Individual Differences, Vol.42, 8I5-824. doi:I0.I0I6/j.paid.2006.09.018.

Hidalgo et.al. (2010). Chapter two: Psychological well-being assessment tools and related factors. In Ingrid E. Wells (ed). Psychological Well-Being(77-I13). New York: Nova Science Publisher.

Harrington, D. (2009). Confirmatory factor analysis. Oxford: University Press

Rathi. (20II). Psychological well-being and organizational commitmnent: Exploration of the relationship. Working-Paper No. I06. India: Amrita School of Business

Ryff, C. D., \& Keyes, C. L. M. (1995). The structure of psychological well-being. Journal of Personality and Social Psychology, 69(4), 719.

Ryff, C. D. (I989). Happiness is everything, or is it? Explorations on the meaning of psychological wellbeing. Journal of Personality and Social Psychology, 57, 6, I069-I08I.

Umar, Jahja. (20II). Analisis faktor konfirmatorik. Bahan perkuliahan. Fakultas Psikologi. UIN Jakarta. Tidak dipublikasikan.

Vieira, Armando Luis. (20II). Interactive LISREL in practice. London: Springer. 